\title{
RĪGAS PILSĒTVIDE TŪRISMA ATTĪSTĪBAS KONTEKSTĀ: VIETĖJO IEDZĪVOTĀJU ATTIEKSME
}

\author{
Maija Rozīte', Aija van der Steina ${ }^{2}$, Albert Postma ${ }^{3}$ \\ ${ }^{1}$ Biznesa augstskola Turïba, e-pasts: Maija.Rozite@turiba.Iv \\ ${ }^{2}$ Latvijas Universitātes Ekonomikas un vadības fakultāte, e-pasts: aija.vdSteina@lu.lv \\ 3 The European Tourism Futures Institute, e-pasts: Albert.Postma@stenden.com
}

\begin{abstract}
Anotācija. Tūrisms mūsdienās attīstās dažādās vietās un vidēs, tai skaitā pilsētas vidē. Tūristu pieredzes veidošanā liela nozīme ir ne tikai tūrisma objektiem un pakalpojumiem, bet arī pilsētas psihologiskajai pievilcībai un sociālajai viesmīlībai (sociālai atmosfērai, gaisotnei, vietējo iedzīvotāju attieksmei). Tādējādi pilsētas tūrisma attīstībā nozīmīga ir vietējo iedzīvotāju attieksme, bet tā savukārt ir atkarīga no tūrisma radītajām pārmaiņām pilsētas telpā. Rakstā tiek analizēti trīs dažādu pētījumu rezultāti par Rīgas iedzīvotāju attieksmi pret tūrisma attīstību, sākot no 1998. gada un beidzot ar 2015. gada pētījumu. Lai gan pagājis neliels laika sprīdis, Rīgā būtiski ir mainījusies vietējo iedzīvotāju attieksme. Lai gan tā kopumā ir l,oti pozit̄̄va, tomēr ir identificēti vairāki negatīvi ietekmes veidi, kur veidojas kritiskās sadursmes starp tūristiem, tūrisma attīstību un vietējiem iedzīvotājiem, kas var novest pie vietējo iedzīvotāju negatīvas attieksmes un tās izpausmēm, tas ir, mazināt Rīgas kā pilsētas pievilcību. Pilsētas un tūrisma attīstības plānotājiem nepieciešams pievērst uzmanību tādiem tūrisma ilgtspējīgas attīstības indikatoriem kā pilsētvides fiziskajai un sociālajai kapacitātei, piẹ̦aujamo pārmaiņu robežai.
\end{abstract}

Atslēgas vārdi: pilsētvide, tūrisma ietekme, vietējo iedzīvotāju attieksme, kritiskā sadursme.

Pilsētu tūrismā, kas mūsdienās ir kḷuvis par vienu no straujāk augošajiem tūrisma sektoriem pasaulē, liela nozīme tiek pievērsta pilsētas telpai kopumā: pilsētas aktivitātei, gaisotnei, tradīcijām, drošumam, vietējo iedzīvotāju attieksmei, laipnībai, draudzīgumam, izpalīdzīgumam (Jansen-Verbeke 1986; Hall, Page 2006; Ashworth, Page 2011). Atsevišksos pētījumos ir identificētas tādas pilsētvides dimensijas kā pilsētas 
psiholoǵiskā pievilcība un sociālā viesmīlība (Lashley 2000; Bell 2007; Hayllar, Griffin, Edwards 2008).

Daudzu pētījumu rezultāti liecina, ka vietējo iedzīvotāju attieksme pret tūristiem un tūrisma iespējamo ietekmi ir nozīmīgs tūrisma vietu ilgtspējīgas attīstības faktors, tāpēc vietējo iedzīvotāju attieksme pret tūrismu un izpratne par tūrisma ietekmi ir jānovērtē nepārtraukti.

Neatkarības atjaunošana bija impulss straujai starptautiskā tūrisma attīstībai. Laika posmā no 1995. līdz 2014. gadam Rīgas pilsētas naktsmītṇu kapacitāte (gultas vietu skaits) ir pieaugusi 2,5 reizes, bet nakšn,ojošu viesu skaits pat 8 reizes, sasniedzot 2,4 miljonus nakšņojumu 2014. gadā, no kuriem 2,1 miljons ir ārvalstu viesu pārnakšņojumi (CSP 2016). No starptautiskā tūrisma tirgū neatpazītas pilsētas Rīga pēdējā desmitgadē ir kḷuvusi par populāru nedēḷas nogales tūrisma galamērḳi Eiropā. Pilsētas centrā ir izveidojušās tūrisma ainavas raksturīgākās iezīmes (Terkenli 2002) un tūrisma rajons - telpa, kurā uzturas tūristi, ir koncentrēti tūrisma nozares uzṇēmumi un tūrisma pakalpojumu sniedzēji (Rozīte 2011). Augot pilsētas viesu skaitam, palielinās tūrisma intensitāte (tūristu / vietējo iedzīvotāju skaita attiecība). Tūristi ne tikai izmanto, bet arī maina ainavas un to identitāti, atstāj ne tikai sociālas, bet arī telpiskas pēdas (Terkenli 2002).

Starptautiskā tūrisma attīstību Rīgā ir ietekmējuši dažādi iekšējie un ārējie faktori, tai skaitā tādi, kuri ir veicinājuši tūrisma negatīvās izpausmes un ietekmes. Kopš 2005. gada lidojumus uz Rīgu sāka zemo izmaksu lidsabiedrības (Ryanair, Easy Jet, Norwegian), kas turpmākajos gados sekmēja Rīgā pirms tam nebijušu tūrisma veidu izklaides tūrismu, kura raksturīgākās izpausmes bija vecpuišu ballītes. Rīdzinieki bija spiesti vērot, kā pilsētā uzplaukst izklaides un nakts dzīves industrija, radot arī šīm funkcijām atbilstošas ainavas pašā pilsētas centrā. Publikācijas ārvalstu plašsaziņas līdzekḷos par Rīgu kā uzdzìves vietu veidoja negatīvu Rīgas pilsētas tēlu, un 2009. gadā Rīgā pat tika izveidota Tūrisma policija.

Iedzīvotāju attieksmes skaidrojumos izmanto dažādas teorijas un modeḷus. CAC (Cognitive, Affective, Conative angl.) modelis balstās uz indivīda attieksmes trīs komponentēm: izziņas, emocionālo un izturēšanās komponenti (Andriotis, Vaughan 2003). Pirmajā Rīgas iedzīvotāju attieksmes pētījumā (Upchurch, Teivane 2000) novērtēta izziņas komponente, vēlākajos pētījumos (Rozīte, Steina 2013; Postma 2015) novērtētas arī emocionālā un izturēšanās komponente.

2012. gada pētījumā, novērtējot vietējo iedzīvotāju saskarsmi ar tūristiem, kā arī viṇu attieksmi pret dažādiem tūrisma ietekmes veidiem un tūrisma attīstību Rīgā, tika izmantota tiešās intervijas metode un semi strukturēta anketa. Izvērtējot attieksmi pret tūrisma ietekmi uz saimniecību, infrastruktūru, sabiedrību un kultūru, tika piedāvāti apgalvojumi, kas bija jānovērtē Likerta skalā no 1 līdz10. Respondentiem bija jānorāda arī dz̄ives vieta, dz̄̄ves ilgums Rīgā, iesaiste tūrismā un saskarsmes biežums ar tūristiem (Rozīte, Steina 2013).

2014./2015.g. Eiropas Tūrisma nākotnes pētniecības tīklā tika veikts kopējs pētījums Amsterdamā, Berlīnē un Rīgā. Tajā tika iegūti dati par kritiskajām sadursmēm 
(critical encounters) (Postma 2015), kas rodas starp vietējiem iedzīvotājiem un tūrisma attīstības aspektiem. Pētījumā izmantota kvalitatīvo pētījumu metode - padzilinātās intervijas ar vietējiem iedzīvotājiem, noskaidrojot vietējo iedzīvotāju attieksmi pret tūrisma attīstību pilsētā. Rīgā tika intervēti 25 respondenti, kurus atlasīja pēc tādām pazīmēm kā vecums, dzimums, dzimšanas un dzīves vieta, saistība ar tūrismu.

2012. gada pētījumā tika vērtēti vairāki aspekti, tai skaitā tie faktori, kas ietekmē pilsētas vidi. Rīdzinieku kopējais vērtējums par tūrisma ietekmi uz pilsētas infrastruktūru ir pozitīvs, $(\bar{x}=6.7)$. Augstu novērtēta tūrisma nozīme uzṇēmējdarbības dažādošanā, attīstot kafejnīcas, restorānus, veikalus $(\bar{x}=8,06)$, kā arī novērotas tūrisma attīstības rezultātā augošas preču un pakalpojumu cenas $(\bar{x}=7.18)$. Lielākās pārmaiņas ir izjustas brīvā laika vidē $(\bar{x}=7.48)$, vēsturisko vietu saglabāšanā un atjaunošanā $(\bar{x}=7,11)$, pilsētas dabas vides uzlabošanā $(\bar{x}=7,11)$. Centra iedzīvotāji ir kritiskāki, uzsverot tādas negatīvas ietekmes veidus kā vairāk atkritumu pilsētā $(\bar{x}=6,24)$, lielāks piesārņojums $(\bar{x}=5,54)$, augošie satiksmes sastrēgumi un stāvvietu problēmas $(\bar{x}=5.23)$. Augstu novērtēta ietekme uz sabiedrību un kultūru - atzīts, ka tūrisms veicina un dažādo kultūras pasākumus Rīgā ( $\bar{x}=7,52)$, veicina saskarsmi starp dažādu kultūru pārstāvjiem $(\bar{x}=7,26)$. Visaugstāko novērtējumu ,, loti ietekmē” $(\bar{x}=8,2)$ ir ieguvis apgalvojums ,attīsta nakts dz̄ivi”, kā arī „veicina prostitūciju” (7,04), veicina alkoholismu pilsētā $(\bar{x}=6,43)$, ubagošanu uz ielas $(\bar{x}=6,16)$.

2014./2015. gada pētîjums sniedz padziḷinātu skaidrojumu par vietējo iedzīvotāju saskarsmi ar tūrismu jeb kritiskās sadursmes, viņu attieksmi un reakciju. Vērtējot tādu pilsētas vides aspektu kā infrastruktūru, visvairāk kritisko sadursmju (13) ir radušās tūrisma attīstības rezultātā, saskaroties dažādu grupu interesēm. Te var minēt stāvvietu un autobusu novietošanas problēmas, ekskursiju autobusu klātbūtni un izskatu Rīgā, infrastruktūras elementu stāvokli un pieejamību, taksometru pakalpojumu cenas. Taču jāuzsver, ka respondenti novērtē arī tūrisma attīstības pozitīvo ietekmi, ko atklāj apgalvojums: „Tūrisms ir palīdzējis izveidot Rīgā labu infrastruktūru, kas ir arī laba vietējiem." [R25].

Identificēti vairāki negatīvo sadursmju veidi, kas saistīti ar tūristu klātbūtni un izturēšanos. Visbiežāk minēta tūristu uzvedība un vecpuišu ballītes, troksnis un pūḷi Vecrīgā, lielas tūristu grupas Alberta ielā, augošs tūristu skaits radošajos kvartālos, neapmierinātu tūristu izturēšanās. Raksturojot tūrisma netiešo ietekmi ikdienas dz̄ivē, minēti tādi ietekmes veidi kā ielu muzikantu izpildījums tūristiem, ilgāka iepirkšanās lielveikalos (tūristus apkalpo ilgāk), augstās dzīvokḷu cenas centrā.

Iedzīvotāju emocijas un rīcība visspilgtāk izpaudusies saskarsmē ar tūristiem. Rīdzinieki paši nav proaktīvi, bet palīdz, ja redz, ka tūristiem jau ir radušās problēmas: „Man to tūristu bija tik žēl, ka gāju vin,iem iztulkot.” [R5]. Visemocionālāko reakciju ir izraisījusi „,ballīšu” tūristu uzvedība, kas izpaužas tādās respondentu atbildēs kā „Man nepatīk” [R14], ,Mani kaitina” [R7], ,Es kḷūstu dusmīgs” [R25], „Nejutos komfortabli.” [R11, R14]. Respondentu reakcija uz troksni un burzmu ir nepatika un cenšanās izvairīties no šādām vietām [R1, R21]. 
Jāuzsver, ka daḷa respondentu šajā pētījumā vispirms uzsvēra tūrisma attīstības un ietekmes pozitīvos faktorus un tikai pēc tam raksturoja negatīvās sadursmes, piemēram, „Tūristi ienes pozitīvu un internacionālu gaisotni.” [R8]. Tajā pašā laikā vietējie iedzīvotāji norāda, ka tūrisms ir jāattīsta, ņemot vērā Rīgas kapacitāti: „Tūristu skaits nākotnē ir jāregulē. Man ir negatīva pieredze Prāgā, kur tajās cilvēku masās nebija iespējams baudīt pilsētu." [R1]. Lai gan veidojas personīgs diskomforts, tiek pieņemta tūrisma attīstība, jo tas dod ekonomisku labumu: „Man nepatīk lielas cilvēku masas, bet no ekonomiskā viedokḷ tas nav slikti." [R21].

Starptautiskais tūrisms Rīgā, izmantojot Batlera tūrisma vietas dzīves cikla teoriju, īsā laikā ir nonācis attīstības stadijā, kad aug tūrisma produktu un pakalpojumu apjoms un parādās tūrisma ietekmes problēmas.

Rīdzinieki ir ne tikai informēti un izpratuši tūrisma iespējamo ietekmi, bet spējuši to arī novērtēt. Tūrisma attīstība iedzīvotāju skatījumā ir uzlabojusi pilsētas vidi, it sevišḳi tās kafejnīcu, restorānu un veikalu pakalpojumu daudzveidību, radītas jaunas atpūtas vietas, labiekārtoti parki. Tas ir veicinājis saskarsmi starp dažādu kultūru pārstāvjiem Rīgā un palielinājis pilsētas iedzīvotāju ienākumus. Bet tūrisms ir veicinājis arī dzīves dārdzības, preču un pakalpojumu cenu pieaugumu, palielinājis atkritumu daudzumu, veicinājis vides piesārņojumu. Īpaši uzsvērta tūrisma loma naktsdzīves attīstībā un prostitūcijas veicināšanā. Rīgas centra iedzīvotāji augstāk ir vērtējuši tādus negatīvus ietekmes aspektus kā transporta sastrēgumu veidošanos, drūzmu pilsētā un tradicionālās ainavas iznīcināšanu.

Kvalitatīvie, padziḷinātie pētījumi norāda uz iedzīvotāju kritiskāku attieksmi, novērtējot ne tikai tūrisma fizisko ietekmi, bet arī vizuālo uztveres (netipiskais ekskursiju autobusu izskats, tūristu nepieņemamā uzvedība) ietekmi. Tūrisma ilgtspējīgas attīstības nodrošināšanai ir jāveic padziḷināti ietekmes pētījumi, novērtējot tādus ilgtspējīgas attīstības indikatorus kā vides un sociālo kapacitāti un pieḷaujamo pārmaiņu robežu.

\section{Atsauces}

Andriotis, K., Vaughan, R. D. (2003). Urban Residents' Attitudes toward Tourism Development: The Case of Crete, Journal of Travel Research, 42, 172-185

Ashworth, G., Page S.J. Urban tourism Research: Recent progress and current paradoxes, Tourism Management, 32, 1-15.

Bell, D. (2007). The hospitable city: social relations in commercial spaces. Progress in Human Geography, 31(1), 7-22.

Centrālā statistikas pārvalde. Ikgadējie statistikas dati. Tūrisms: http://data.csb.gov.lv/pxweb/lv/transp/transp_ikgad_turisms/?tablelist=true\&rxid=cdcb978c-

22b0-416a-aacc-aa650d3e2ce0 (05.02.2016)

Hall, C., M., Page, S. J. (2006). The geography of tourism and recreation. Environment, place and space. $3^{\text {rd }}$.ed. London and New York: Routledge.

Hayllar, B., Griffin, T., Edwards, D. (2008). City spaces - tourist places: urban tourism precincts. Oxford: Elsevier. 
Jansen-Verbeke, M. (1986). Inner-city tourism: resources, tourists and promoters, Annals of Tourism Research, 13(1), 79-100.

Lashley, C. (2000). Towards a theoretical understanding. Lashley, C. , Morrison, A., (eds.) In search of hospitality: theoretical perspectives and debates. Oxford: Butterworth Heinemann, 1-17.

Postma, (2015). Overuse of City Destinations: Limits and Solutions. Referāts ITB Berlin Convention, Berlīne, 2015.gada 5.marts.

Rozite, M. (2011). Tourism landscape - significant, desirable, surprising or unexpected feature of Riga. ATLAS annual conference 2011. Landscape and tourism: the dualistic relationship. Valmiera, Latvia September 2011. Abstract book. Vidzemes augstskola, 43.

Rozīte, M., V.d. Steina A. (2013). Rīgas iedzīvotāju attieksme kā nozīmīgs ilgtspējīga tūrisma attīstības kritērijs. XIV Starptautiskā zinātniskā konference. Radīt nākotni: komunikācija, izglītība, bizness darbam. Biznesa augstskola Turība.

Terkenli, T.S. (2002). Landscapes of tourism: towards a global cultural economy of space? Tourism Geographies, 4 (3), 227-254.

Upchurch, R.S, Teivane, U. (2000). Resident perceptions of tourism development in Riga, Latvia. Tourism Management. 21, 499-507.

\section{Summary}

Modern day tourism is developing in a variety of places and environments, including the urban environment. In addition to tourist attractions, a city's psychological attraction and hospitality (social atmosphere, ambience, local inhabitant attitudes) play a significant role in the formation of the tourist experience. Therefore, the attitude of local inhabitants is significant for the development of urban tourism, which in turn is dependent on the changes brought about by tourism in the city environment. The present article analyses the results of three different studies conducted on the attitude of local inhabitants towards tourism development in Rìga during the period of 1998 - 2015. Regardless of the comparatively short period under discussion, the attitude of local inhabitants in Rīga has changed considerably. Although attitudes are generally very positive, several negative impact factors were identified in areas where a critical conflict exists between tourists and local inhabitants, which have the potential to lead to negative attitudes among local inhabitants. The expression of these attitudes towards tourists in turn could decrease the attractiveness of Riga. City and tourism developers have to pay attention to sustainable tourism indicators such as physical and social carrying capacity and the limit of acceptable changes. 